\title{
Peningkatan Kemampuan Berpikir Kreatif Melalui Penerapan Project Based Learning Pada Materi Pencemaran dan Daur Ulang Limbah
}

\section{Enhancement of Creative Thinking Ability through the Implementation of Project Based Learning on Material and Waste Recycling}

\author{
Gilang Akbar Nugroho ${ }^{1}$, Baskoro Adi Prayitno ${ }^{1}$, Joko Ariyanto ${ }^{1 *}$ \\ ${ }^{1}$ Pendidikan Biologi, Fakultas Keguruan dan Ilmu Pendidikan, Universitas Sebelas Maret. Surakarta 57126, Indonesia \\ *Corresponding authors: gilangakbar111@student.uns.ac.id
}

Manuscript received: ......... Revision accepted:

\begin{abstract}
This study aims to improve the ability of creative thinking through Project Based Learning on pollution and waste recycling materials. This research is a classroom action research conducted for 2 cycles. Each research cycle consists of 4 stages, namely planning, action, observation, and reflection. The subjects of the study were the students of grade X SMA N 2 Boyolali with 37 students. Research data obtained through class observation, interviews, documentation, and tests of creative thinking ability that consists of aspects of fluency, flexibility, originality, and elaboration. Validation of data is done by triangulation technique. Data analysis using qualitative descriptive analysis technique. The results showed that each aspect of creative thinking ability in pre-cycle that is fluency $25,4 \%$ included in category less, flexibility $24,8 \%$ included in category less, originality 15,9\% included in category less, and elaboration 18,6\% Included in the category less. The achievement percentage of each aspect of the ability of creative thinking in the first cycle that is fluency $34.5 \%$ included in the category enough, flexibility $41.8 \%$ included in the category enough, originality $37 \%$ included in the category enough, and elaboration $40.5 \%$ included in the category enough. The achievement percentage of each aspect of creative thinking ability in cycle II that is fluency 78,6\% included in creative category, flexibility 52,1\% included in enough category, 48,9\% originality included in enough category, and elaboration 58,6\% including In sufficient category. The achievement of students' creative thinking ability from pre-cycle to cycle II has increased according to the research target of $\geq 20 \%$ through the implementation of Project Based Learning model.
\end{abstract}

Keywords: Project based learning, creative thinking ability, waste recycling

\section{PENDAHULUAN}

Kemampuan berpikir kreatif diperlukan oleh siswa Indonesia sebagai bekal menghadapi MEA (Masyarakat Ekonomi ASEAN) dan Bonus Demografi. MEA merupakan bentuk kerja sama antar anggota ASEAN untuk mengadakan perdagangan bebas (Triyonggo, Maarif, Sukmawati, \& Baga, 2015). Adanya bentuk kerja sama ini menimbulkan persaingan di bidang produk dan ketenaga kerjaan (Triyonggo et al., 2015; Wibowo, 2015).

Badan Pusat Statistik (2013) melaporkan bahwa Indonesia segera memasuki gerbang bonus demografi pada tahun 2020-2035. Bonus demografi merupakan fenomena jumlah penduduk usia produktif lebih banyak dibandingkan dengan penduduk usia non produktif. Bonus demografi dapat dimaknai sebagai peluang jika masyarakat mampu mengelola dengan baik situasi tersebut, tetapi jika tidak dikelola dengan baik bonus demografi berdampak pada banyaknya pengangguran di Indonesia (Maryati, 2015; Gunawan, 2014).

Pentingnya kemampuan berpikir kreatif juga diamanahkan oleh Peraturan Menteri Pendidikan dan Kebudayaan Republik Indonesia No 69 Tahun 2013 yang menyebutkan bahwa kurikulum 2013 bertujuan untuk menyiapkan manusia Indonesia agar memiliki kemampuan hidup sebagai warga negara yang beriman, produktif, kreatif, inovatif, dan afektif serta mampu berkontribusi pada kehidupan bermasyarakat, berbangsa, bernegara, dan peradaban dunia. Susantini (2016) mengatakan bahwa kemampuan berpikir kreatif dan inovasi merupakan salah satu kunci menghadapi persaingan. Kemampuan berpikir kreatif rendah berdampak pada kesulitan siswa menyelesaikan permasalahan pembelajaran (Mulyasa, 2009).

Kemampuan berpikir kreatif merupakan bagian dari kreativitas yang melibatkan pengembangan ide maupun produk terhadap permasalahan (Ulger, 2017). Kemampuan berpikir kreatif menurut Sumarni (2015) terdiri dari aspek fluency, flexibility, originality, dan elaboration. Hasil observasi di kelas X IPS 1 SMA N 2 Boyolali menunjukkan permasalahan kemampuan berpikir kreatif yang rendah. Rendahnya kemampuan berpikir kreatif ditunjukkan dengan perilaku siswa seperti selama kegiatan pembelajaran cenderung diam ketika diminta berpendapat mengenai fenomena oleh guru, gagasan yang disampaikan siswa dalam menyelesaikan masalah masih standar dan terbatas, sedikit sekali siswa yang bertanya maupun menjawab pertanyaan, siswa cenderung diam dan mencatat penjelasan guru secara langsung, waktu yang diperlukan 
siswa untuk menjawab sebuah pertanyaan cukup lama, dan siswa belum mampu memberikan tambahan pada jawaban atau gagasan siswa lain. Berdasarkan angket yang diberikan kepada guru di SMA N 2 Boyoali pada tanggal 11 Januari 2017 mengenai persepsi terhadap kemampuan berpikir kreatif menunjukkan bahwa guru sudah memahami pentingnya kemampuan berpikir kreatif bagi siswa, tetapi pada pelaksanaannya guru belum menerapkan pembelajaran yang dapat memberdayakan kemampuan berpikir kreatif siswa. Ini terlihat dari model pembelajaran yang diterapkan masih konvensional sebatas ceramah dan diskusi tanya jawab, soal lembar kerja cenderung lebih banyak menguji aspek ingatan daripada aspek berpikir kreatif siswa, dan kurangnya pemberian kesempatan kepada siswa untuk menjawab pertanyaan kemampuan berpikir kreatif.

Tes pra-siklus dilakukan untuk mengetahui profil awal siswa. Hasil tes pra-siklus menunjukkan aspek fluency siswa termasuk dalam kategori kurang kreatif dengan persentase $25,4 \%$, aspek flexibility termasuk dalam kategori kurang kreatif dengan persentase $24,8 \%$, aspek originality termasuk dalam kategori kurang kreatif dengan persentase $15,9 \%$, dan aspek elaboration juga termasuk dalam kategori kurang kreatif dengan persentase $18,6 \%$. Hasil tersebut didukung penelitian (Rahayu, Susanto, \& Yulianti, 2011) yang mengklasifikasi kemampuan berpikir kreatif berdasarkan tiga kategori, kreatif ditunjukkan dengan skala 68\%-100\%, cukup kreatif 33\%-67\%, dan kurang kreatif $<33 \%$.

Pembelajaran yang dapat memberdayakan kemampuan berpikir kreatif salah satunya dengan menerapkan model Project Based Learning (PjBL). PjBL merupakan model pembelajaran yang bersifat konstruktif melalui aktivitas dan pengalaman nyata yang bermakna (Siwa, Muderawan, \& Tika, 2013). PjBL memberikan kesempatan kepada siswa untuk terlibat aktif dalam aktivitas pembelajaran dan memberikan kepercayaan untuk mengungkapkan gagasan melalui penyelesaian proyek (Mrayyan, 2016). Sintaks $\mathrm{PjBL}$ meliputi start with the essential question, design a plan for the project, create a schedule, monitor the students and the progress of the project, assess the outcome, dan, evaluate the experience (Sumarni, 2015).

Materi yang dipilih dalam penelitian ini adalah pencemaran dan daur ulang limbah. Pemilihan materi didasarkan pertimbangan bahwa pencemaran dan daur ulang limbah memerlukan pemahaman lebih dibandingkan dengan materi kelas X lainnya. Siswa diharapkan dapat melihat permasalahan limbah dari berbagai sudut pandang dan dituntut untuk mengambil keputusan sebagai upaya pemecahan masalah, sehingga siswa lebih aktif berpikir.

Tujuan penelitian ini adalah meningkatkan kemampuan berpikir kreatif melalui penerapan Project Based Learning pada materi pencemaran dan daur ulang limbah kelas X IPS 1 SMA N 2 Boyolali.

\section{METODE PENELITIAN}

Penelitian merupakan Penelitian Tindakan Kelas (PTK) yang dilaksanakan selama 2 siklus, masing-masing siklus terdiri dari tahap perencanaan (planning), pelaksanaan (action), pengamatan (observation), dan refleksi (reflecting). Setiap siklus merupakan penerapan model PjBL pada sub materi pencemaran air, pencemaran udara, dan daur ulang limbah.

Subjek penelitian adalah siswa kelas X IPS 1 SMA N 2 Boyolali sejumlah 37 siswa. Data penelitian diperoleh melalui observasi, wawancara dokumentasi, dan tes. Data Penelitian diperoleh melalui observasi kelas, wawancara, dokumentasi, dan tes kemampuan berpikir kreatif yang terdiri dari aspek fluency, flexibility, originality, dan elaboration. Validasi data dilakukan dengan teknik triangulasi. Analisis data menggunakan teknik analisis deskriptif kualitatif. Indikator ketercapaian penelitian adalah peningkatan persentase sebesar $\geq 20 \%$.

\section{HASIL PEMBAHASAN}

Hasil tes kemampuan berpikir kreatif pada pra-siklus menunjukkan rata-rata persentase sebesar $21,2 \%$ dengan persentase masing-masing aspek yaitu fluency $25,4 \%$ termasuk dalam kategori kurang kreatif, flexiblity 24,8\% termasuk dalam kategori kurang kreatif, originality 15,9\% termasuk dalam kategori kurang kreatif, dan elaboration $18,6 \%$ termasuk dalam kategori kurang kreatif. Perbaikan kemampuan berpikir kreatif siswa kelas X IPS 1 SMA N 2 Boyolali yang termasuk dalam kategori kurang kreatif dilakukan dengan menerapkan model project based learning.

\section{Siklus I}

Pelaksanaan siklus I dilakukan pada submateri pencemaran air dan pencemaran udara, diawali dengan menyajikan fenomena ke dalam pembelajaran melalui simulasi pencemaran air dan udara yang dilakukan oleh siswa. Adanya fenomena yang dihadirkan menuntut siswa melihat permasalahan dari berbagai sudut pandang sehingga memunculkan gagasan-gagasan untuk menyelesaikan permasalahan melalui pertanyaan mendasar. Produk yang dihasilkan pada siklus I adalah poster pencemaran. Hasil tes kemampuan berpikir kreatif masing-masing siswa siklus I dapat dilihat pada Gambar 1.

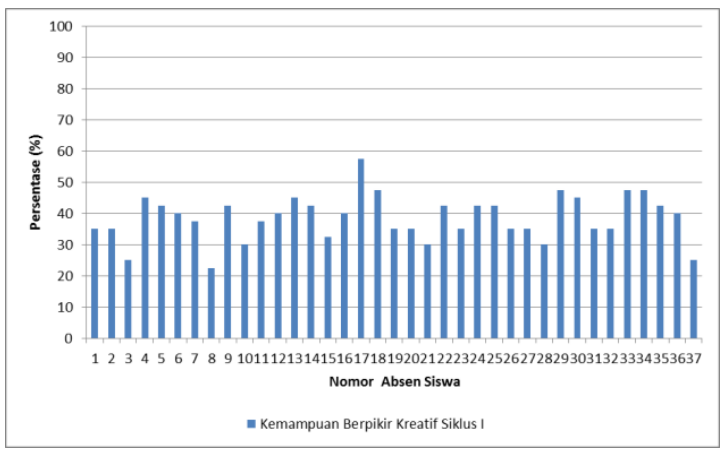

Gambar 1. Hasil tes kemampuan berpikir kreatif masing-masing siswa siklus I

Gambar 1 menunjukkan bahwa rentang persentase kemampuan berpikir kreatif siswa siklus I adalah 22,5\% $57,5 \%$ dengan rata-rata $38,5 \%$ yang termasuk dalam kategori cukup kreatif. Adapun capaian persentase masing- 
masing aspek yaitu fluency $34,5 \%$ termasuk dalam kategori cukup kreatif, flexibility $41,8 \%$ termasuk dalam kategori cukup kreatif, originality $37 \%$ termasuk dalam kategori cukup kreatif, dan elaboration $40,5 \%$ termasuk dalam kategori cukup kreatif.

Berdasarkan data hasil tes siklus I diperoleh informasi bahwa terdapat peningkatan rata-rata persentase masingmasing aspek kemampuan berpikir kreatif dari pra-siklus ke siklus I. Aspek fluency meningkat sebesar 9,1\%, aspek flexibility meningkat $17 \%$, aspek originality meningkat $21,1 \%$, dan aspek elaboration meningkat $21,9 \%$.

Temuan permasalahan pembelajaran siklus I diantaranya sebagai berikut: (1) siswa tidak mengamati fenomena menggunakan keseluruhan indra sehingga memengaruhi efektivitas waktu, (2) sebagian besar siswa belum mampu berpikir out of the box sehingga jawaban tes kemampuan berpikir kreatif mengacu pada temuan dalam bacaan soal tes, dan (3) beberapa siswa tidak fokus terhadap pertanyaan soal tes sehingga menjawab dengan tidak tepat.

\section{Siklus II}

Pelaksanaan siklus II dilakukan pada submateri daur ulang limbah, diawali dengan menghadirkan fenomena limbah di lingkungan. Produk yang dihasilkan pada siklus II adalah produk daur ulang limbah. Hasil tes kemampuan berpikir kreatif masing-masing siswa siklus II dapat dilihat pada Gambar 2.

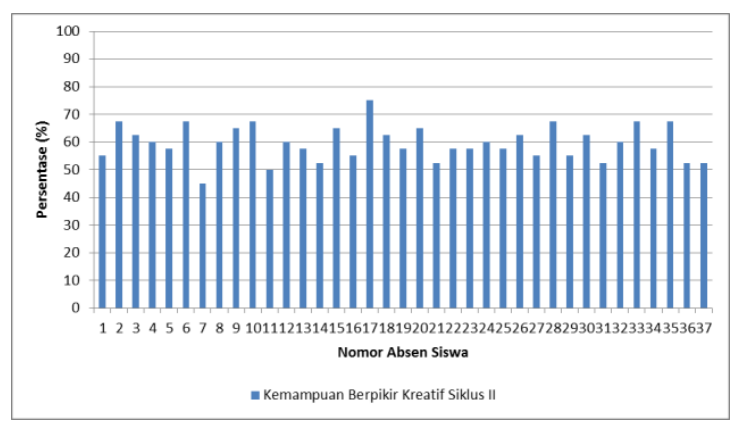

Gambar 2. Hasil tes kemampuan berpikir kreatif masing-masing siswa siklus II

Gambar 2 menunjukkan bahwa rentang persentase kemampuan berpikir kreatif siswa siklus II adalah 55\% $75 \%$ dengan rata-rata 59,5\% yang termasuk dalam kategori cukup kreatif. Adapun capaian persentase masing-masing aspek yaitu fluency 78,6\% termasuk dalam kategori kreatif, flexibility $52,1 \%$ termasuk dalam kategori cukup kreatif, originality 48,9\% termasuk dalam kategori cukup kreatif, dan elaboration 40,5\% termasuk dalam kategori cukup kreatif.

Berdasarkan data hasil tes siklus II diperoleh informasi bahwa terdapat peningkatan rata-rata persentase masingmasing aspek kemampuan berpikir kreatif dari pra-siklus ke siklus II. Aspek fluency meningkat sebesar 53,2\%, aspek flexibility meningkat $27,3 \%$, aspek originality meningkat $33 \%$, dan aspek elaboration meningkat 40\%. Dengan demikian, target penelitian berupa adanya peningkatan persentase sebesar $\geq 20 \%$ pada masing-masing aspek kemampuan berpikir kreatif telah tercapai.

\section{Perbandingan Seluruh Siklus}

Kemampuan berpikir kreatif siswa mengalami peningkatan dari pra-siklus sampai dengan siklus 2. Perbandingan capaian persentase kemampuan berpikir kreatif dari prasiklus sampai dengan siklus II disajikan pada Gambar 3.

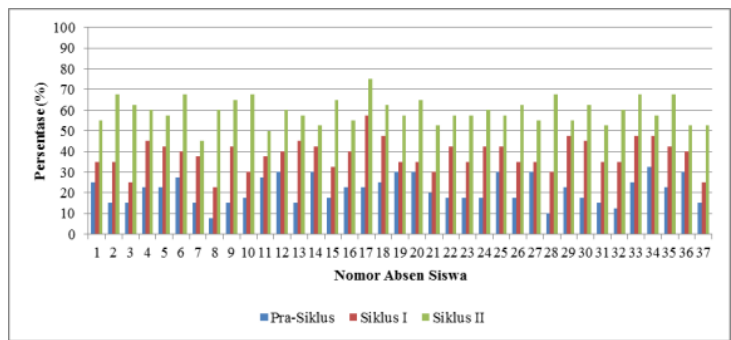

Gambar 3. Perbandingan capaian persentase kemampuan berpikir kreatif seluruh siklus

Gambar 3 menunjukkan bahwa kemampuan berpikir kreatif siswa mengalami peningkatan cukup baik melalui penerapan model $\mathrm{PjBL}$ dari pra-siklus sampai dengan siklus II. (Rahayu et al., 2011) mengklasifikasi kemampuan berpikir kreatif berdasarkan tiga kategori, kreatif ditunjukkan dengan skala 68\%-100\%, cukup kreatif 33\%$67 \%$, dan kurang kreatif $<33 \%$. Siklus I menunjukkan ratarata capaian persentase kemampuan berpikir kreatif siswa sebesar 38,5\% termasuk dalam kategori cukup kreatif. Capaian persentase masing-masing aspek di siklus I adalah fluency $34,5 \%$; flexibility 41,8\%, originality $37 \%$, dan elaboration $40,5 \%$. Kemampuan berpikir kreatif siklus II menunjukkan rata-rata capaian persentase $59,5 \%$ termasuk dalam kategori cukup kreatif. Capaian persentase masingmasing aspek di siklus II adalah fluency 78,6\%; flexibility $52,1 \%$, originality $48,9 \%$, dan elaboration $58,6 \%$ sehingga menunjukkan adanya peningkatan persentase masingmasing aspek kemampuan berpikir kreatif.

Hasil analisis menunjukkan bahwa kemampuan berpikir kreatif siswa mengalami peningkatan bervariasi dari pra-siklus sampai dengan siklus II. Meskipun demikian, peningkatan yang dicapai tidak keseluruhan dapat menaikkan level kemampuan berpikir kreatif siswa pada siklus I. Siswa dengan nomor absen 3, 8, 10, 15, 21, 28, 37 memiliki rentang rata-rata kemampuan berpikir kreatif $22,5 \%$ - 32,5\% yang termasuk dalam kategori kurang kreatif. Perbaikan yang dilakukan terhadap permasalahan pembelajaran siklus I menunjukkan hasil cukup baik dengan meningkatnya level kemampuan berpikir kreatif siswa dari kurang kreatif menjadi cukup kreatif pada siklus II. Peningkatan yang melebihi target penelitian ditunjukkan dengan capaian persentase sebesar $75 \%$ termasuk dalam kategori kreatif oleh siswa nomor absen 17 pada siklus II. Kemampuan berpikir kreatif yang mengalami peningkatan pada pembelajaran siklus I dan II dibandingkan dengan pra-siklus menunjukkan bahwa PjBL mampu memberdayakan kemampuan berpikir kreatif siswa. Pendapat senada disampaikan oleh (Utami, 
Probosari, \& Fatmawati, 2015) yang mengatakan bahwa tahapan model PjBL berpotensi mengembangkan kemampuan berpikir kreatif. PjBL menekankan pada aktivitas dan keterlibatan siswa dalam pembelajaran serta memberikan kesempatan dan kepercayaan kepada siswa untuk mengungkapkan gagasan melalui penyelesaian proyek sehingga menghasilkan pemikiran-pemikiran yang kreatif (Mrayyan, 2016; Salam, Mailok, Ubaidullah, \& Ahmad, 2016). Menurut Alkiyumi (2010) kemampuan berpikir kreatif dapat diberdayakan melalui aktivitas pembelajaran yang mengarah kepada berpikir kreatif; menfasilitasi siswa belajar dengan fenomena, masalah, gambar, maupun objek yang menimbulkan pertanyaan dan multi tafsir.

\section{KESIMPULAN}

Berdasarkan hasil penelitian dapat dilakukan simpulan bahwa terdapat peningkatan persentase kemampuan berpikir kreatif siswa dari level kurang kreatif menjadi cukup kreatif sehingga model Project Based Learning efektif meningkatkan kemampuan berpikir kreatif siswa.

\section{DAFTAR PUSTAKA}

Alkiyumi, M. T. M. (2010). Creative Thinking And Problem-Solving Abilities: Their Relationship With Psychological Traits Among 10th-Grade Students in Oman. Universiti Sains Malaysia.

Gunawan, W. (2014). Adaptabilitas: Strategi Menghadapi Afta Dan Memanfaatkan Bonus Demografi. Jurnal NEOTIC Psychology, 4, 110-126.

Maryati, S. (2015). Dinamika Pengangguran Terdidik: Tantangan Menuju Bonus Demografi Di Indonesia. Journal of Economic and Economic Education, 3(2).

Mrayyan, S. (2016). Investigating Mathematics Teachers Role to Improve Students ' Creative Thinking. American Journal of Educational Research, 4(1), 8290.

Mulyasa. (2009). Menjadi Guru Profesional Menciptakan Pembelajaran Kreatif dan Menyenangkan. Bandung: Remaja Rosdakarya.
Rahayu, Susanto, \& Yulianti. (2011). Pembelajaran sains dengan pendekatan keterampilan proses untuk meningkatkan hasil belajar dan kemampuan berpikir kreatif siswa. Jurnal Pendidikan Fisika Indonesia, 7, 106-110.

Salam, F., Mailok, R., Ubaidullah, N., \& Ahmad, U. (2016). The Effect Of Project Based Learning Against Students's Engagement. International Journal of Development Research, 6, 6891-6895.

Siwa, I. B., Muderawan, I. W., \& Tika, I. N. (2013). Pengaruh Pembelajaran Berbasis Proyek Dalam Pembelajaran Kimia Terhadap Keterampilan Proses Sains Ditinjau Dari Gaya Kognitif Siswa. E-Journal Program Pascasarjana Universitas Pendidikan Ganesha, 3(3), 1-13.

Sumarni, W. (2015). The Strengths and Weaknesses of the Implementation of Project Based Learning : International Journal of Science and Research (IJSR), 4 (3), 478-484.

Susantini, E. (2016). Effectiveness of genetics student worksheet to improve creative thinking skills of teacher candidate students. Journal of Science Education, 17(11), 74-79.

Triyonggo, Y., Maarif, M. S., Sukmawati, A., \& Baga, L. M. (2015). Analisis Situasional Kompetensi Praktisi Sumber Daya Manusia Indonesia Menghadapi MEA 2015. Jurnal Manajemen Teknologi, 14 (1).

Ulger, K. (2017). The Relationship Between The Creativity And The Creative Thinking Skills Observed In Students.

Utami, R. P., Probosari, R. M., \& Fatmawati, U. M. I. (2015). Pengaruh Model Pembelajaran Project Based Learning Berbantu Instagram Terhadap Kemampuan Berpikir Kreatif Siswa Kelas X Sma Negeri 8 Surakarta. Bio-Pedagogi, 4 (4), 47-52.

Wibowo, B. K. (2015). Peranan Manajer Sumber Daya Manusia (Sdm) Dalam Penarikan (Rekruitmen) Di Era Masyarakat Ekonomi Asean (MEA). Jurnal STIE Semarang, 7(3), 13-30. 